\title{
Analisis dan Pengukuran Tingkat Ketergunaan (Usability) Penggunaan Website E-learning di Jurusan Ilmu Komputer Universitas Negeri Semarang
}

\author{
Usability Analysis and Measurement of E-learning Website in Computer Science
}

Department at Universitas Negeri Semarang

\author{
Ryo Pambudi*1, Florentina Yuni Arini ${ }^{2}$ \\ 1,2 Jurusan Ilmu Komputer dan Elektronika, FMIPA Unnes, Semarang \\ e-mail: *11ryopambudi87@students.unnes.ac.id, ${ }^{2}$ floyuna@mail.unnes.ac.id
}

\begin{abstract}
Abstrak
E-learning merupakan suatu jenis media untuk melakukan proses belajar mengajar secara mandiri yang memungkinkan tersampaikan bahan ajar ke mahasiswa melalui media jaringan komputer atau internet. E-learning semakin banyak digunakan oleh lembaga pendidikan karena mempermudah para pengguna untuk dapat mengakses dimanapun dan kapanpun tanpa adanya pembatasan ruang dan waktu sehingga mahasiswa dapat dengan leluasa memperoleh materimateri kuliah yang ditempuh. Tetapi untuk e-learning yang berbasis web ini dirasa masih banyak yang kekurangan sehingga dirasa sangat sulit digunakan atau tidak menarik penggunanya dan tidak dipakai secara efektif dan efisien sebagaimana mestinya. Hal ini dikarenakan usability pada web tidak diperhatikan sehingga hubungan interaksi antara manusia yang merupakan salah satu faktor penting dalam sebuah sistem terabaikan. Usabilitas terdiri dari learnability (mudah dipelajari), efficiency (efisien), memorability (kemudahan dalam mengingat), errors (pencegahan kesalahan), dan satisfaction (kepuasan pengguna). Penelitian ini bertujuan untuk mengukur seberapa tinggi tingkat usabilitas yang telah ada pada sistem dan bagaimana respon pengguna terhadap web e-learning tersebut. Hasil penelitian adalah tingkat usability dari website e-learning sehingga dapat mengetahui kriteria apa saja yang belum diperbaiki sebagai dasar pengembangan user interface dari e-learning tersebut.
\end{abstract}

Kata kunci-E-learning, usability, learnability, efficiency, memorability, errors, satisfaction

\begin{abstract}
E-learning is a type of media to perform the process of teaching and learning independently which allows conveyed teaching materials to students through the media or computer network internet. E-learning is increasingly used by educational institutions because it makes it easy for users to be able to access anywhere and anytime without any limitation of space and time so that students can freely obtain the course materials taken. But for e-learning that is based on the web is still considered a lot of shortcomings so it is very difficult to use or not attract users and not used effectively and efficiently as it should. This is because usability on the web is not considered so that the interaction between human beings is one important factor in a neglected system. Usability consists of learnability, efficiency, memorability, errors, and satisfaction. This study aims to measure how high the level of reusability that already exist in the system and how the user response to the web e-learning. The result of the research is the usability level of the e-learning website so that it can know what criteria have not been improved as the basis of user interface development from e-learning.
\end{abstract}

Keywords - E-learning, usability, learnability, efficiency, memorability, errors, satisfaction

\section{PENDAHULUAN}

Kemajuan akan teknologi infromasi pada sekarang ini telah berpengaruh di bebagai bidang kehidupan, mulai dari lingkungan keluarga hingga masyarakat, termasuk pada bidang 
pendidikan[1]. Perkembangan teknologi yang sangat cepat salah satunya yaitu internet. Internet memungkinkan terjadinya pertukaran informasi yang cepat dan akurat serta tidak terbatas terhadap ruang dan waktu[2]. Dalam internet tersebut terdapat website yang menjadi sumber informasi untuk dikases oleh setiap pengguna. Dari website tersebut terjadilah pertukaran informasi para pengguna internet[3]. Salah satu jenis website yang dimanfaatkan oleh sekolah dan perguruan tinggi adalah website e-learning. E-learning merupakan suatu jenis media untuk melakukan proses belajar mengajar secara mandiri yang memungkinkan tersampaikan bahan ajar ke mahasiswa melalui media jaringan komputer atau internet[1]. E-learning semakin banyak digunakan oleh lembaga pendidikan karena mempermudah para pengguna untuk dapat mengakses dimanapun dan kapanpun tanpa adanya pembatasan ruang dan waktu sehingga mahasiswa dapat dengan leluasa memperoleh materi-materi kuliah yang ditempuh.

Setelah diketahui manfaat yang ditawarkan banyak orang berlomba-lomba unrtuk membuat e-learning sebagai media pembantu perkuliahan, akan tetapi mengalami cukup banyak kendala. Kendala yang didapat seperti sering terjadinya salah persepsi manusia (pengguna) terhadap e-learning yang ada, sehingga bukan efektivitas dan efisiensi kerja yang diperoleh, akan tetapi justru menyebabkan pembelajaran tidak efisien dan efektif, pengguna sering mengalami kesulitan menggunakan e-learning tersebut karena tidak familiar dengan e-learning, e-learning terlalu rumit sehingga sulit dipelajari, e-learning tidak sesuai dengan kebutuhan pengguna dan tidak atau belum mengakomodasi kebutuhan yang penting bagi pengguna[4]. Hal tersebut terjadi karena pendesain dan programmer dari system tersebut kurang memperhatikan faktor interaksi manusia dan komputer atau human computer interaction (HCI). Ada beberapa penyebab proses interaksi manusia dengan komputer menjadi kurang efisien yaitu keterbatasan kemampuan para pengguna untuk mengoperasikan sistem yang tidak dikenal atau baru bagi pengguna, dan perancang perlu memahami pskologi dari calon pengguna sehingga interaksi antara manusia dan komputer dapat terbangun secara baik[5].

Usability dalam interaksi manusia dan komputer merupakan bagian penting yang harus terpenuhi dalam perancangan sebuah sistem e-learning. Menurut Jacob Nielsen, usability adalah sebuah atribut kualitas yang menilai tingkat kemudahan user interface untuk digunakan[5]. Usability dalam website e-learning menjadi komponen yang penting karena menjadi salah satu faktor penentu keberhasilan suatu sistem. Suatu website e-learning pada dasarnya harus dapat dipahami dan digunakan oleh penggunanya sehingga manfaat dari e-learning tersebut dapat dirasakan oleh pengguna. Adanya 5 komponen yang harus dipenuhi agar suatu website memiliki usability yang ideal, yaitu: Learnability (Mudah dipelajari), Efficiency (Efisien), Memorability (Kemudahan dalam mengingat), Errors (Pencegahan kesalahan), dan Satisfaction (Kepuasan pengguna)[5].

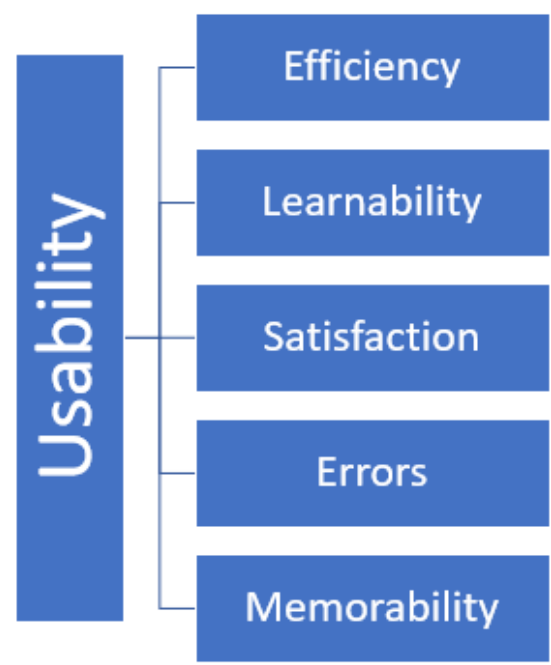

Gambar 1. Atribut Usability 
Learnability mengindikasikan seberapa mudah bagi pengguna untuk memmpelajari dan menjalankan sistem tersebut pertama kali. Efficiency menunjukkan tingkat seberapa cepat pengguna dapat menyelesaikan tugasnya menggunakan sistem tersebut. Memorability yaitu saat dimana pengguna harus menggunkan sistem tersebut kembali setelah lama idak menggunakan, seberapa mudah pengguna dapat mengingat dan menjalankan sistem tersebut dengan baik dan benar. Errors menandakan seberapa banyak kesalahan yang dilakukan oleh pengguna, seberapa parah kesalahan ini dan seberapa mudah mereka keluar dari kesalahan tersebut. Satisfaction mengindikasikan seberapa puas pengguna dalam menggunakan sistem tersebut.

\section{METODE PENELITIAN}

Penelitian yang dilakukan menggunkan metode penelitian deskriptif, dimana dalam pelaksanaanya terdiri dari pengumpulan data, analisis dan interpretasi arti dan data yang diperoleh. Pengumpulan data merupakan salah satu aspek penting dalam penelitian ini karena perannya dalam kelancaran dan keberhasilan dalam suatu penelitian. Metode pengumpulan kuesioner adalah teknik pengumpulan data melalui formulir-formulir yang berisi pertanyaanpertanyaan yang diajukan secara tertulis pada seseorang atau sekumpulan orang untuk mendapatkan jawaban atau tanggapan dan informasi yang diperlukan oleh peneliti. Dalam penelitian ini metode pengumpulan data yang digunakan adalah Angket atau Kuesioner yang disebar melalui online menggunakan google form. Bentuk pertanyaan adalah pilihan ganda (multiple choice questions) dan pertanyaan bersifat tertutup (closed ended question). Skala pengukuran variabel dalam penelitian ini mengacu pada Skala Likert (Likert Scale), dimana masing-masing dibuat dengan menggunakan skala $1-5$ kategori jawaban, yang masing-masing jawaban diberi score (nilai) atau bobot yaitu banyaknya score antara 1 sampai 5, dengan rincian sebagai berikut[6]:

1. Jawaban SB (Sangat Baik) diberi nilai 5

2. Jawaban B (Baik) diberi nilai 4

3. Jawaban $\mathrm{C}$ (Cukup) diberi nilai 3

4. Jawaban TB (Tidak Baik) diberi nilai 2

5. Jawaban STB (Sangat Tidak Baik) diberi nilai 1

\section{HASIL DAN PEMBAHASAN}

Responden dari penelitian ini adalah mahasiswa aktif jurusan ilmu Komputer Universitas Negeri Semarang yang diambil secara acak sebanyak 50 orang responden yang pernah menggunakan website e-learning http://kuliah.ilkom.unnes.ac.id. Setelah data dari kuisioner di dapatkan kemudian data tersebut diolah dan di analisis. Pertanyaan yang ada di kuisioner dibagi menjadi lima kelompok seperti tabel 1 dibawah ini. 


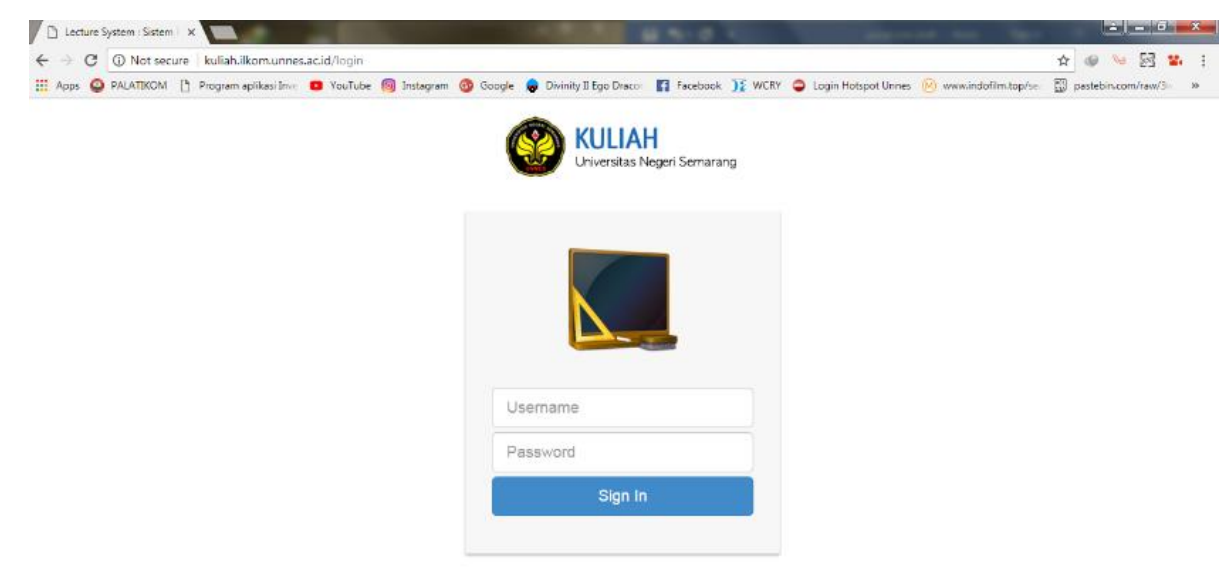

Gambar 1. Tampilan Website E-learning

Tabel 1. Kelompok dan Variabel Data

\begin{tabular}{|c|c|c|}
\hline Variabel & Tipe & Fungsi \\
\hline Semester & Numerik & $\begin{array}{c}\text { Semester yang sedang } \\
\text { ditempuh responden } \\
(1,3,5,7)\end{array}$ \\
\hline Q1-Q3 & Numerik & $\begin{array}{c}\text { Pertanyaan untuk } \\
\text { mengeck tingkatan pada } \\
\text { aspek learnability }\end{array}$ \\
\hline Q5-Q6 & Numerik & $\begin{array}{c}\text { Pertanyaan untuk } \\
\text { mengeck tingkatan pada } \\
\text { aspek } \text { efficiency }\end{array}$ \\
\hline Q7-Q9 & Numerik & $\begin{array}{c}\text { Pertanyaan untuk } \\
\text { mengeck tingkatan pada } \\
\text { aspek memorability }\end{array}$ \\
\hline Q10-Q12 & Numerik & $\begin{array}{c}\text { Pertanyaan untuk } \\
\text { mengeck tingkatan pada } \\
\text { aspek } \text { error }\end{array}$ \\
\hline Q13-Q17 & Numerik & $\begin{array}{c}\text { Pertanyaan untuk } \\
\text { mengeck tingkatan pada } \\
\text { aspek satisfaction }\end{array}$ \\
\hline
\end{tabular}

Dalam penelitian ini akan dilihat apakah secara umum tingkat usabilitas dari aplikasi sistem informasi ini memenuhi kriteria usabilitas menurut Jacob Nielsen, maka pertanyaan kuisioner dibagi dalam 5 kelompok pertanyaan ditambah dengan satu kelompok pertanyaan yang menanyakan profil responden. Kelompok pertanyaan tersebut adalah sebagai berikut:

1. Learnability menjadi ukuran seberapa mudah suatu website atau sistem mudah digunakan. Dalam kuisioner, nilai dari variabel ini didapat dari ratarata jawaban atas pertanyaan no 1-4.

2. Efficiency berhubungan dengan kemampuan menyajikan informasi secara cepat. Dalam kuisioner, nilai dari variabel ini didapat dari ratarata jawaban atas pertanyaan no 5-6.

3. Memorability adalah kemampuan website akan mudah diingat oleh pengguna setelah pengguna tidak menggunakannya alam jangka waktu tertentu. Dalam kuisioner, nilai dari variabel ini didapat dari ratarata jawaban atas pertanyaan no 7-9.

4. Errors berkaitan dengan kesalahan dan kerusakan yang ada pada sistem. Dalam kuisioner, nilai dari variabel ini didapat dari ratarata jawaban atas pertanyaan no 10-12. 
5. Satisfaction yaitu kepuasaan yang diinginkan oleh pengguna setelah menggunakan sistem tersebut. Dalam kuisioner, nilai dari variabel ini didapat dari ratarata jawaban atas pertanyaan no 13-17.

6. Mengukur apakah sistem aplikasi in juga dipengaruhi oleh faktor semester yang sedang ditempuh responden, karena lama penggunaan e-learning juga bergantung seberapa mahasiswa tersebut kuliah menggunakan sistem ini.

Masing-masing pertanyaan didalam kelompok hanya memiliki nilai 1-5. Responden akan mengisi nilai 1 apabila dia 'sangat tidak baik' dengan maksud pertanyaan yang diajukan dan akan mengisi nilai 5 jika dia 'sangat baik' dengan maksud pertanyaan. Hasil perhitungan rata-rata dari masing-masing kriteria dapat dilihat pada Tabel 2.

Tabel 2. Nilai Rata-rata Kriteria Nielsen

\begin{tabular}{|c|c|c|}
\hline Faktor & Jumlah Sampel & Rata-rata \\
\hline Keseluruhan Pengukuan & 50 & 4,051 \\
\hline Learnability & 50 & 4,345 \\
\hline Efficiency & 50 & 4,07 \\
\hline Memorability & 50 & 4,4 \\
\hline Error & 50 & 3,5 \\
\hline Satisfaction & 50 & 3,948 \\
\hline
\end{tabular}

Dari dari tabel 4.2, terlihat jelas bahwa tingkat usability keseluruhan menunjukkan nilai 4,16 dari skala 1-5. Ini menunjukkan bahwa sistem memiliki tingkat usabilitas baik (diatas ratarata) sehingga dapat dikatakan sistem informasi kebijakan pangan sudah user friendly atau mudah digunakan. Sementara masing-masing kriteria usabilitas seperti learnability $(4,345)$, efficiency $(4,07)$, dan memorability $(4,4)$ mengindikasikan semua nilai diatas rata-rata nilai pengukuran keseluruhan. Kondisi nilai itu menyatakan bahwa sistem mudah digunakan, efisien dalam operasinya, dan gampang di ingat dalam menggunakan sistem. Namun error $(3,5)$ dan satisfaction $(3,948)$ masih berada dibawah rata-rata keseluruhan, hal ini mengingat masih ada kesalahan yang terdapat baik pada sistem tersebut maupun dari pengguna dan penggguna masih kurang puas dengan e-learning ini.

Uji validitas dilakukan untuk melihat apakah data yang diperoleh cukup valid untuk masing-masing kriteria. Uji validitas ini dilakukan dengan menghitung rata-rata nilai item Total Correlation dari setiap pertanyaan dalam kelompok kriteria dengan menggunakan korelasi Cronbach, jika nilai rata-ratanya > nilai $r$ maka pertanyaan dalam kelompok kriteria dianggap "valid". Nilai $r=0,279$ diperoleh dari tabel $r$ signifikasi untuk uji dua aeah 0,05 dengan derajat bebas $\mathrm{n}-2$ dimana $\mathrm{n}$ adalah jumlah responden sehingga nilai yang digunakan dalam kasus ini adalah tabel $r$ dengan derajat bebas 48 . Hasilnya dapat dilihat pada Tabel 3.

Tabel 3. Uji Validitas Cronbach

\begin{tabular}{|c|c|c|}
\hline Faktor & $\begin{array}{c}\text { Rata-rata Corrected } \\
\text { Total Correlation }\end{array}$ & Kesimpulan \\
\hline Learnability & 0,589 & Valid \\
\hline Efficiency & 0,682 & Valid \\
\hline Memorability & 0,692 & Valid \\
\hline Error & 0,482 & Valid \\
\hline Satisfaction & 0,691 & Valid \\
\hline
\end{tabular}

Selanjutnya dengan dengan uji statistik Cronbach juga dilakukan untuk melihat reliabilitas (kehandalan) data. Hasilnya adalah seperti pada tabel 4. 
Tabel 4. Reliabilitas Statistik Cronbach

\begin{tabular}{|c|c|}
\hline Cronbach's Alpha & N of item \\
\hline 0,920 & 17 \\
\hline
\end{tabular}

Dari Tabel 4 tersebut diatas dapat dilihat bahwa nilai crobach'alpha $=0,920$. Sebuah instrumen dikatakan reliabel (handal) untuk mengukur variabel bila memiliki nilai alpha lebih besar dari 0,60 yang dapat dilihta klasifikasinya pada tabel 5[9]. Dengan nilai alpha=0,920 maka item pertanyaan instrumen yang dipakai untuk mengukur drajat usabilitas sistem website $e$ learning dapat dikatakan sangat tinggi.

Tabel 5. Kriteria Indeks Reliabilitas

\begin{tabular}{|c|c|}
\hline $\begin{array}{c}\text { Kriteria indeks } \\
\text { reliabilitas }\end{array}$ & Klasifikasi Nilai \\
\hline $0,800-1,000$ & Sangat Tinggi \\
\hline $0,600-0,800$ & Tinggi \\
\hline $0,400-0,600$ & Sedang \\
\hline $0,200-0,400$ & Rendah \\
\hline $0.000-0,200$ & Sangat Rendah \\
\hline
\end{tabular}

Selanjutnya akan dilakukan pengukuran apakah ada pengaruh semester secara signifikan terhadap setiap kriteria usabilitas Neilson. Perhatikan Chi Square Test pada Tabel 6 berikut. Dari Tabel 6 kita lihat bahwa nilai Chi Square Test pada semua kriteria nilai lebih dari 0,05 yang menjadi syarat berpengaruh atau tidak ada pengaruh semester yang ditempuh secara signifikan terhadap kriteria yang diperlukan.

Tabel 6. Chi Square Test Terhadap Semester

\begin{tabular}{|c|c|c|}
\hline Faktor & Chi Square Tests & Kesimpulan \\
\hline Learnability & 0,114 & Tidak Berpengaruh \\
\hline Efficiency & 0,031 & Berpengaruh \\
\hline Memorability & 0,016 & Berpengaruh \\
\hline Error & 0,482 & Tidak Berpengaruh \\
\hline Satisfaction & 0,316 & Tidak Berpengaruh \\
\hline
\end{tabular}

Tabel 6. menunjukkan bahwa pengguna website e-learning ini menunjukkan bahwa faktor semester cukup berpengaruh secara signifikan pada beberapa kriteria, terlihat untuk kriteria Efficiency dan memorability ternyata mempunyai nilai yang kecil dibanding kriteria yang lain, disebabkan setiap pengguna membutuhkan e-learning yang dapat menampilkan informasi yang efektif, efisien dan mudah untuk diingat dalam penggunaanya.

Kondisi ini menunjukkan bahwa sistem aplikasi website sudah user friendly (ramah terhadap pengguna). Dari hasil berbagai uji coba diatas, hasil penelitian tentang Tingkat Ketergunaan (Usability) website e-learning ini dapat diresumekan kedalam tabel 7 berikut:

Tabel 7. Tingkat Ketergunaan (Usability)

\begin{tabular}{|c|c|c|c|}
\hline Kriteria Nielsen & $\mathrm{U}$ & $\mathrm{V}$ & $\mathrm{S}$ \\
\hline Learnability & 4,345 & Valid & TB \\
\hline Efficiency & 4,07 & Valid & B \\
\hline Memorability & 4,4 & Valid & B \\
\hline Error & 3,5 & Valid & TB \\
\hline
\end{tabular}




\begin{tabular}{|l|l|l|l|} 
Satisfaction & 3,948 & Valid & TB \\
\hline
\end{tabular}

Catatan:

$\mathrm{U}=$ Tingkat Ketergunaan

$\mathrm{V}=$ Validitas Data

$\mathrm{S}=$ Pengaruh Semester

$\mathrm{TB}=$ Tidak berpengaruh

$\mathrm{B}=$ Berpengaruh

\section{KESIMPULAN}

Berdasarkan hasil penelitian diatas maka dapat diambil kesimpulan sebagai berikut :

a. Sistem memiliki tingkat ketergunaan (usability) baik (diatas rata-rata sekitar 81\%) sehingga dapat dikatakan website e-learning ini memiliki kriteria user friendly yang baik.

b. Dari lima kriteria, 3 kriteria yaitu Learnability, Efficiency, dan Memorability, mengindikasikan bahwa sistem website ini mudah digunakan, lebih efisien, dan mudah diingat cara mengoperasikan sistem tersebut.

c. Kriteria Error dan Satisfaction berada dibawah rata-rata nilai keseluruhan. Disebabkan masih ada kesalahan yang terdapat baik pada sistem tersebut maupun dari pengguna dan penggguna masih kurang puas dengan e-learning ini.

d. Instrumen pengujian yang digunakan dalam penelitian ini dinyatakan "valid" dan "reliabel" karena memenuhi metode uji statistik Cronbach.

e. Pengaruh semester terhadap usability Nielsen ternyata ada dua kriteria yaitu Efficiency dan Memorability yang dipengaruhi secara signifikan oleh semester, sementara tiga kriteria lainnya tidak dipengaruhi oleh semester.

\section{SARAN}

Dalam penelitian selanjutnya dapat diperbanyak responden untuk mengetahui apakah akan menghasilkan hasil yang sesuai pada penelitian ini dan dapat diperbanyak faktor-faktor eksternal yang dapat dilakukan Chi Square Test untuk mengetahui faktor-faktor apa saja yang berpengaruh.

\section{UCAPAN TERIMA KASIH}

Terima kasih kepada taman-teman mahasiswa dan seluruh dosen program studi Teknik Informaika, Universitas Negeri Semarang atas dukungan dalam terlaksanakannya penelitian ini.

\section{DAFTAR PUSTAKA}

[1] Aminoto, T. 2014. Penerapan Media E-Learning Berbasis Schoology untuk Meningkatkan Aktivitas dan Hasil Belajar Materi Usaha dan Energi di Kelas XI SMA N 10 Kota Jambi. Sainmatika: Jurnal Sains dan Matematika Universitas Jambi, 8(1). 
[2] Hayati, R. 2014. Analisis Website Pemerintah Provinsi Riau Dengan Metode User Centered Design (UCD) (Doctoral dissertation, Universitas Islam Negeri Sultan Syarif Kasim Riau).

[3] Irsyad, M., Slamet, C., \& Susanto, A. 2013. Perancangan Website Sekolah Pada Subsystem User Interface (Study Kasus Di Pesantren Persis 99 Rancabango). Jurnal Algoritma, 9(01).

[4] Lestariningsih, T. 2017. Analisis Sitem Informasi Dalam Perspektif Human Computer Interaction. Jurnal AKSI (Akuntansi dan Sistem Informasi), 1(1), 5-9.

[5] Mazumder, F., \& Das, U. 2014. Usability guidelines for usable user interface. International Journal of Research in Engineering and Technology, 3(9), 79-82.

[6] Handiwidjojo, W., \& Ernawati, L. 2016. Pengukuran Tingkat Ketergunaan (Usability) Sistem Informasi Keuangan Studi Kasus: Duta Wacana Internal Transaction (Duwit). Jurnal Informatika dan Sistem Informasi, 2(1), 49-55. 